\title{
Bromatological composition and dry matter digestibility of millet cultivars subjected to nitrogen doses
}

\author{
[Composição bromatológica e digestibilidade da massa seca de cultivares de milheto \\ submetidos à doses de nitrogênio] \\ W.H.D. Buso ${ }^{1}$, A.F.S. França ${ }^{2}$, E.S. Miyagi ${ }^{2}$ \\ ${ }^{1}$ Instituto Federal Goiano - Câmpus Ceres - GO \\ ${ }^{2}$ Universidade Federal de Goiás - Goiânia, GO
}

\begin{abstract}
The bromatological composition and in vitro dry matter digestibility of millet cultivars were assessed for different nitrogen doses and two sowing seasons in the Ceres municipality of Goiás state, Brazil. The treatments consisted of three millet cultivars (ADR-7010, ADR-500 and BRS-1501), four nitrogen (N) doses $\left(0,50,100\right.$ and $200 \mathrm{~kg} \mathrm{ha}^{-1}$ of $\left.\mathrm{N}\right)$ and two sowing seasons. Three replicates and a randomised block design with a $3 \times 4 \times 2$ factorial scheme were used. Two cuttings were performed in each season when plants reached an average height of $0.70 \mathrm{~cm}$. No significant interactions were observed between or among cultivars for $\mathrm{N}$ doses and dry matter (DM), crude protein (CP), neutral detergent fibre (NDF) and acid detergent fibre (ADF) contents. The DM, CP, NDF and ADF contents were significantly different between $\mathrm{N}$ doses. The DM and CP contents increased as the $\mathrm{N}$ dose increased to $100 \mathrm{~kg} \mathrm{ha}^{-1}$. The maximum DM and CP contents were 11.14 and $22.53 \%$, respectively. The NDF and ADF contents were higher in the control treatment $(60.11$ and $30.01 \%$, respectively). In addition, the lowest ADF and NDF concentrations occurred at an $\mathrm{N}$ dose of $50 \mathrm{~kg} \mathrm{ha}^{-1}(56.33$ and $30.23 \%$, respectively). The DM contents were higher for the February sowing, with an average of $10.59 \%$. The highest CP and ADF contents were found for the December sowing (22.46 and 31.58\%, respectively). No significant differences were found for millet cultivars, $\mathrm{N}$ doses or sowing seasons. A significant interaction was found between sowing season and millet cultivar. The BRS-1501 cultivar had a higher in vitro dry matter digestibility in the December/2010 sowing (73.88\%).
\end{abstract}

Keywords: fibres, forage, dry matter, Pennisetum glaucum, protein, urea

\section{RESUMO}

Foram avaliadas a composição bromatológica e a digestibilidade in vitro da massa seca de cultivares de milheto, sob doses de nitrogênio, em duas épocas de semeadura, no município de Ceres, Goiás. Os tratamentos foram constituídos por três cultivares de milheto: (ADR-7010, ADR-500 e BRS-1501) e quatro doses de N (0, 50, 100 e 200 $\mathrm{kg} \mathrm{ha}^{-1}$ de N) e duas épocas de semeadura, com três repetições. Utilizou-se o delineamento de blocos ao acaso em esquema fatorial 3x4x2. O fatorial foi avaliado em duas épocas de semeadura (dezembro/2010 e fevereiro/2011). Foram realizados dois cortes em cada época, quando as plantas atingiram, em média, 0,70m de altura. Não foi observada interação significativa entre as cultivares e dose de $\mathrm{N}$ e para os teores de MS, PB, FDN, FDA. Entre as cultivares de milheto, não houve diferença significativa para as mesmas variáveis. Ocorreu diferença significativa para os teores de MS, PB, FDN e FDA, entre as doses de $N$. Os teores de MS e PB aumentaram até a dose de $100 \mathrm{~kg} \mathrm{ha}^{-1}$ de N. Os teores máximos de MS e PB foram de $11,14 \%$ e 22,53\%, respectivamente. Os teores de FDN $(60,11 \%)$ e FDA $(30,01 \%)$ foram maiores no tratamento controle, enquanto as menores concentração foram determinadas com a aplicação da dose equivalente a $50 \mathrm{~kg}$ $\mathrm{ha}^{-1}$ de N, em que o FDN foi de 56,33\% e o FDA de 30,23\%. Os teores de MS foram maiores na semeadura de fevereiro, com média de 10,59\%. Os maiores teores de PB (22,46\%) e FDA (31,58\%) foram determinados na semeadura de dezembro. Não foram observadas diferenças significativas para as cultivares de milheto, as doses de $N$ e as épocas de semeadura. Ocorreu efeito significativo para a interação entre épocas de semeadura e cultivares de milheto. A cultivar BRS-1501 apresentou maior DIVMS na semeadura de dezembro/2010 $(73,88 \%)$.

Palavras-chave: fibras, forragem, matéria seca, Pennisetum glaucum, proteína, ureia

Recebido em 10 de abril de 2013

Aceito em 13 de dezembro de 2013

E-mail: wilian.buso@ifgoiano.edu.br 


\section{INTRODUCTION}

Pearl millet (Pennisetum glaucum (L.) Leeke) is an annual forage crop with high nutritional value. Pearl millet can be used for grain production, ground cover, grazing and silage production. Due to its physiological features, this forage is highly resistant to water stress and adapts well to acidic and oligotrophic soil conditions, which are limiting conditions for maize and sorghum cultivation (Pires et al., 2007).

Pearl millet can be used for grazing during the summer as an alternative to native grazing crops. Pearl millet can produce five times more forage than native fields. Thus, the stocking rate and the liveweight gain per area are higher for pearl millet. The bromatological value of pearl millet varies throughout the grazing cycle (Santos et al., 2005).

The nutritional value of the forage depends on its chemical and physical composition. These two properties and the digestibility of the food influence the intake and metabolism of the food. Forage should provide nutrients, protein, energy, minerals and vitamins for the development of the animals (Van Soest, 1994).

Dry matter (DM), crude protein $(\mathrm{CP})$ and neutral detergent fibre (NDF) values of 15.2, 16.4 and $61.9 \%$, respectively, were reported by Costa et al. (2011). In this study, the vegetative growth of millet during grazing conditions was assessed for 35 days before placing the animals in the paddock.

Working with three cutting ages (35, 42 and 49 days), Kollet et al. (2006) found that the production of dry matter increased with cutting age. The crude protein contents of the dry matter decreased by $18 \%$ at 35 days and by $13.66 \%$ at 49 days. For the same cutting age, the NDF content increased from 54.30 to $69.17 \%$, and the acid detergent fibre (ADF) content increased from 31.43 to $36.97 \%$. These changes resulted from the reduction of leaf blades and the increase of stems, which contributed to an increase of fibrous components.

According to Fagundes et al. (2006), the supply of adequate $\mathrm{N}$ during forage plant development plays an important role in pasture growth. This result occurs because the $\mathrm{N}$ from organic matter mineralisation does not meet the needs of highly productive forage plants.

Simili et al. (2008) assessed Sudan grass hybrids under different $\mathrm{N}$ doses $\left(100,200\right.$ and 300kgha ${ }^{-1}$ ) and found that $\mathrm{N}$ did not significantly affect the in vitro digestibility of organic matter $(71.8,73.9$ and $71.6 \%$, respectively).

The present study aimed to assess the bromatological composition and in vitro dry matter digestibility of pearl millet cultivars that were fertilised with nitrogen for two sowing seasons in the Ceres municipality of Goiás (GO) state, Brazil.

\section{MATERIALS AND METHODS}

The experiment was conducted at the Federal Institute of Goiás experimental farm on the Ceres Campus (Fazenda Experimental do IFGoiano) in the Ceres municipality (at a latitude of $15^{\circ} 21^{\text {' }}$ $00^{\prime}$ ' $\mathrm{S}$, a longitude of $49^{\circ} 35^{\prime} 57^{\prime}, \mathrm{W}$ and $564 \mathrm{~m}$ above sea level). The regional climate is classified as Aw by the Köeppen classification system, which indicates a hot and semi humid climate with well-defined seasons. The average annual precipitation is $1550 \mathrm{~mm}$. The rainfall is well-defined, with a rainy season occurring from October to April and a dry season occurring from May to September.

The soil in the experimental area is classified as dystrophic red latosol (oxisol) (EMBRAPA, 2006). Soil samples were collected at a depth of 0 to $20 \mathrm{~cm}$ for chemical characterisation. The following results were obtained: calcium $(\mathrm{Ca})$, magnesium $(\mathrm{Mg})$, aluminium $(\mathrm{Al})$, hydrogen $(\mathrm{H})$ and the CEC were $2.4,1.3,0,3.7$ and $7.67 \mathrm{cmol}_{\mathrm{c}}$ $\mathrm{dm}^{-3}$, respectively; the Melich phosphorous $(\mathrm{P})$ and potassium $(\mathrm{K})$ concentrations were 5.0 and $101 \mathrm{mg} \mathrm{dm}^{-3}$, respectively; the $\mathrm{pH}\left(\mathrm{CaCl}_{2}\right)$ was 5.6; and the base saturation, organic matter content, sand content and clay content were 51.8, $1.5,39$ and $50 \%$, respectively. Soil was prepared with two passes of a disk harrow. After the second pass, the soil was levelled with a levelling harrow one day before sowing.

Treatments consisted of three millet cultivars (ADR-7010, ADR-500 and BRS 1501), four $\mathrm{N}$ doses $\left(0,50,100\right.$ and $\left.200 \mathrm{~kg} \mathrm{~N} \mathrm{ha}^{-1}\right)$ and two sowing seasons (December/2010 and February/2011). A complete randomised block 
design with a factorial scheme of $3 \times 4 \times 2$ was used with three replicates for a total of 72 experimental units.

Sowing was performed manually in two seasons, December/01/2010 and February/20/2011. Each experimental unit consisted of four linear $5 \mathrm{~m}$ rows that were spaced at $0.30 \mathrm{~cm}$ for a total area of $4.5 \mathrm{~m}^{2}$. For phosphate fertilisation, a total of $45 \mathrm{~kg} \mathrm{ha}^{-1}$ of $\mathrm{P}_{2} \mathrm{O}_{5}$ (simple super phosphate) was applied in the sowing furrows. Ten days after germination, potassium was distributed on the surface at $30 \mathrm{~kg} \mathrm{ha}^{-1} \mathrm{~K}_{2} \mathrm{O}$. Nitrogen fertiliser (urea) was applied twice. Next, $60 \%$ of the nitrogen fertiliser was applied ten days after emergence, and $40 \%$ was applied the day after the first cutting evaluation.

The two central rows were used after eliminating $0.50 \mathrm{~cm}$ from their ends. In the first sowing season, cuttings were performed on January $5^{\text {th }}$ and $27^{\text {th }}, 2011$. In the second sowing season, cuttings were performed on March $27^{\text {th }}$ and April $21^{\text {st }}, 2011$. Cutting evaluations were performed when at least $50 \%$ of the plants reached a height of $0.70 \mathrm{~cm}$.

Samples of approximately $500 \mathrm{~g}$ were collected for laboratory analysis and were dried at $60^{\circ} \mathrm{C}$ for 72 hours in a convection oven to determine their dry mass. Next, the samples were ground in a Wiley mill (Thomas Scientific, Swedesboro, NJ, USA) with 1-mm sieves. The samples from the two cutting events within their respective seasons were mixed and homogenised for later laboratory analysis. Cuttings were not evaluated alone because the first $\mathrm{N}$ fertilisation influenced the second harvesting.

The analyses for determining bromatological composition, DM, CP, NDF and ADF were performed at the Laboratory of Animal Nutrition in the Department of Animal Production at the Federal University of Goiás Veterinary School.

$\mathrm{DM}$ and $\mathrm{CP}$ contents were determined as described by Silva and Queiroz (2002). NDF and ADF contents were measured following the methods of Van Soest (1994).

The in vitro dry matter digestibility (IVDDM) was determined at the Laboratory of Animal Nutrition in the Department of Animal Production at the Federal University of Grande
Dourados (Universidade Federal da Grande Dourados - UFGD) in the state of Mato Grosso do Sul (MS) as described by Tilley and Terry (1963) and modified by Silva and Queiroz (2002). Ruminal liquid was obtained from four rumen fistulated Nelore cattle at an average age of 30 months. Animals remained in individual stalls for 15 days during the adaptation period. Rumen digesta was removed in the morning when the animals were fasting, and the liquid phase was stored in a thermal bottle that was preheated to $39^{\circ} \mathrm{C}$. This liquid was immediately taken to the laboratory to inoculate the samples.

Bromatological composition and IVDDM data were subjected to analysis of variance (ANOVA), which included the two sowing seasons. The means were compared with the Tukey test at a 5\% significance level. Analyses were performed using the $\mathrm{R}$ software ( $\mathrm{R}$ Development Core Team, 2010).

\section{RESULTS}

No significant $(\mathrm{P}>0.05)$ interactions were found between cultivars and $\mathrm{N}$ doses, between $\mathrm{N}$ doses and sowing seasons, between cultivars and sowing seasons or between sowing season, cultivar and $\mathrm{N}$ dose for the DM, CP, NDF, ADF and IVDDM variables.

No significant differences $(\mathrm{P}>0.05)$ were found among the millet cultivars. However, the ADR500 cultivar had the greatest DM concentration with an average value of $10.36 \%$. The ADR7010 and BRS-1501 cultivars had average DM values of 10.25 and $10.20 \%$, respectively.

Significant differences $(\mathrm{P}<0.05)$ were found between $\mathrm{N}$ dose and the DM, CP, NDF and ADF contents. This difference increased for $\mathrm{N}$ doses of up to $100 \mathrm{~kg} \mathrm{ha}^{-1}$ (Table 1).

A significant difference was found for DM contents between sowing seasons $(\mathrm{P}<0.05)$, which averaged 9.95 and $10.59 \%$ for the December/2010 and February/2011 sowing seasons, respectively. The higher DM concentration in the February sowing was potentially caused by decreased rainfall and increased solar radiation. 
Table 1. The average dry matter (DM), crude protein $(\mathrm{CP})$, neutral detergent fibre (NDF) and acid detergent fibre (ADF) contents of the millet cultivars that were subjected to different nitrogen doses

\begin{tabular}{ccccc}
\hline $\begin{array}{c}\text { N doses } \\
\left(\begin{array}{c}\text { kg ha } \\
1\end{array}\right)\end{array}$ & $\begin{array}{c}\text { DM } \\
(\%)\end{array}$ & $\begin{array}{c}\text { CP } \\
(\%)\end{array}$ & $\begin{array}{c}\text { NDF } \\
(\%)\end{array}$ & $\begin{array}{c}\text { ADF } \\
(\%)\end{array}$ \\
\hline 0 & $8.90 \mathrm{c}$ & $20.35 \mathrm{~b}$ & $60.11 \mathrm{a}$ & $32.00 \mathrm{a}$ \\
50 & $10.54 \mathrm{~b}$ & $21.89 \mathrm{a}$ & $56.33 \mathrm{~b}$ & $30.23 \mathrm{~b}$ \\
100 & $11.14 \mathrm{a}$ & $22.53 \mathrm{a}$ & $57.13 \mathrm{~b}$ & $31.03 \mathrm{ab}$ \\
200 & $10.50 \mathrm{~b}$ & $21.87 \mathrm{a}$ & $57.90 \mathrm{~b}$ & $30.60 \mathrm{ab}$ \\
\hline $\mathrm{CV}(\%)$ & 5.64 & 6.43 & 3.08 & 6.15
\end{tabular}

Means followed by the same letters are statistically similar according to Tukey's test at a $5 \%$ probability level.

As shown in Figure 1, a quadratic effect occurred for $\mathrm{DM}$ contents as a function of $\mathrm{N}$ dose. However, beginning with $126 \mathrm{~kg} \mathrm{ha}^{-1}$ of $\mathrm{N}$, the DM content of the millet shoots decreased.

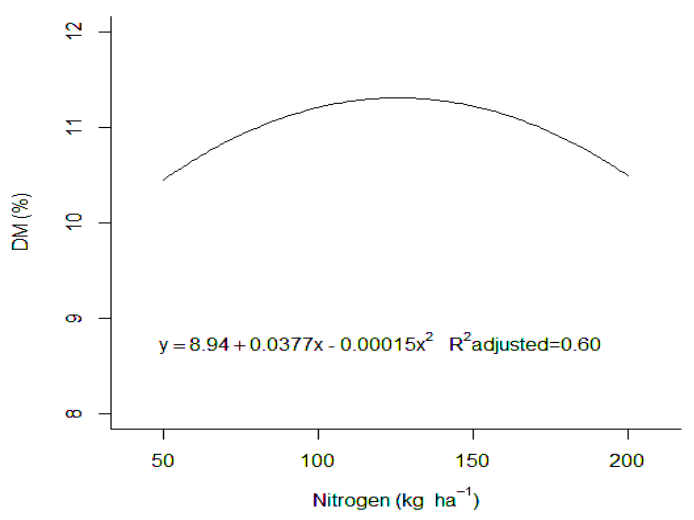

Figure 1. Dry matter content in response to nitrogen applications.

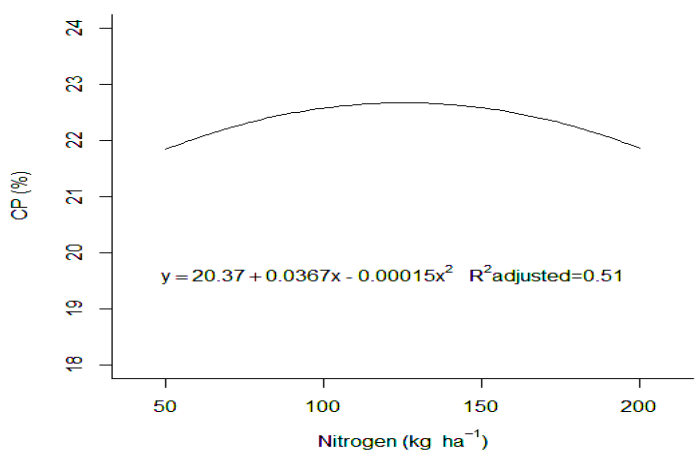

Figure 2. Crude protein contents in response to $\mathrm{N}$ application.
The CP contents were significantly different between sowing seasons $(\mathrm{P}<0.05)$ with average values of 22.46 and $20.86 \%$ for December and February, respectively.

No significant differences were found between millet cultivars for NDF and ADF contents. The ADR-500 cultivar had the greatest NDF content $(58.11 \%)$. The ADR-7010 and BRS-1501 cultivars had NDF contents of 57.74 and $57.75 \%$, respectively. Furthermore, the ADR-500 cultivar had the greatest ADF content $(31.08 \%)$ and the ADR-7010 and BRS-1501 cultivars had ADF contents of 31.03 and $30.80 \%$, respectively.

The control treatment had the highest NDF content, which differed significantly from the other treatments. This result was possibly caused by lower $\mathrm{N}$ availability. For the remaining doses, the means were statistically similar. No significant differences $(\mathrm{P}>0.05)$ were found for the NDF and ADF contents between the sowing seasons.

There was no significant effect $(\mathrm{P}>0.05)$ between cultivars, $\mathrm{N}$ doses and sowing seasons (Table 2).

Table 2. Mean values of in vitro dry matter digestibility (IVDDM) of millet cultivars that were subjected to different nitrogen doses

\begin{tabular}{lc}
\hline Cultivars & IVDDM $(\%)$ \\
\hline ADR -7010 & $72.88 \mathrm{a}$ \\
ADR -500 & $72.63 \mathrm{a}$ \\
$\mathrm{BRS}-1501$ & $73.33 \mathrm{a}$ \\
\hline Doses of N $\left(\mathrm{kg} \mathrm{ha}^{-1}\right)$ & IVDDM $(\%)$ \\
\hline 0 & $73.01 \mathrm{a}$ \\
50 & $73.05 \mathrm{a}$ \\
100 & $72.69 \mathrm{a}$ \\
200 & $73.02 \mathrm{a}$ \\
\hline Sowing season & IVDDM $(\%)$ \\
\hline December & $72.73 \mathrm{a}$ \\
February & $73.16 \mathrm{a}$ \\
\hline CV $(\%)$ & 2.18 \\
\hline \multicolumn{2}{c}{} \\
& DISCUSSION
\end{tabular}

According to Table 1, the DM content decreased at an $\mathrm{N}$ dose of $200 \mathrm{~kg} \mathrm{ha}^{-1} \mathrm{~N}$. This result was most likely caused by increasing water accumulation in the plant's tissue, which leads to decreasing DM content. The forage plant has a high growth rate due to the optimal climate 
conditions. These conditions result in a short harvesting time.

Costa et al. (2011) reported average DM contents of $15.2 \%$ in millet harvested 35 days after sowing and an $\mathrm{N}$ application of $67 \mathrm{~kg} \mathrm{ha}^{-1}$. According to Reichardt (1985), the water content in forage can increase in response to high $\mathrm{N}$ doses, which reduces DM contents.

Working with three cutting ages (35, 42 and 49 days) and three millet cultivars (African, American and BN-2), Kollet et al. (2006) found that the average $\mathrm{CP}$ content decreased from 19.33 to $13.62 \%$ as harvesting age increased from 35 to 49 days, respectively.

In later millet silage production cuts, Amaral et al. (2008) found that the mean CP contents were 9.50 and $7.13 \%$ when cut 70 and 90 days after sowing, respectively. The results above show decreasing CP content with increasing cutting age.

Brum et al. (2008) found CP contents of $23.71 \%$ 60 days after germination in a millet pasture that was fertilised with $90 \mathrm{~kg} \mathrm{ha}^{-1} \mathrm{~N}$. Camargo et al. (2009) reported an average CP content of $20 \%$ 21 days after germination in a millet pasture that was fertilised with $100 \mathrm{~kg} \mathrm{ha}^{-1} \mathrm{~N}$. These results agree with the results of this study. In this study, high CP contents were found that were most likely caused by the presence of a large number of leaves at cutting. In addition, a CP content of approximately $16.4 \%$ was found in millet grazing areas that were used 35 days after sowing and were fertilised with $67 \mathrm{~kg} \mathrm{ha}^{-1} \mathrm{~N}$ in a study conducted by Costa et al. (2011).

The CP contents from 50, 100 and $200 \mathrm{~kg} \mathrm{ha}^{-1} \mathrm{~N}$ doses were not different $(\mathrm{P}<0.05)$ from the control and had average values of $21.89,22.53$ and $21.87 \%$, respectively.

According to Van Soest (1994), forage plants with $\mathrm{CP}$ contents below $7 \%$ are less digestible because they have low levels of $\mathrm{N}$, which is required for rumen microorganisms. Thus, low levels of $\mathrm{N}$ reduce microorganism populations and influence dry matter intake and digestibility. Therefore, higher $\mathrm{CP}$ contents are needed to supply the food demand of the animals.
Nitrogen is the most important nutrient for increasing forage grass productivity. In addition, $\mathrm{N}$ is the main component of proteins that actively participate in the synthesis of the organic compounds that form the plant structure. Thus, $\mathrm{N}$ is responsible for indispensable plant characteristics, such as leaf and stem size and tiller appearance (Simili et al., 2010).

In the present study, the average $\mathrm{CP}$ contents occur at levels that can fully supply the protein demand that is necessary for improved animal performance (well above the critical $7.0 \%$ level).

Working with three cutting ages (35, 42 and 49 days), Kollet et al. (2006) found that the NDF increased from 54.30 to $69.17 \%$ as cutting age increased from 35 to 49 days, respectively. In addition, Kollet et al. (2006) found that the ADF content increased from 31.43 to $36.97 \%$ during this period. These changes resulted from the reduced leaf blades and increased stem biomass, which increased the fibrous fraction.

The control treatment had the highest ADF concentration $(32.00 \%)$. This concentration only differed from the $50 \mathrm{~kg} \mathrm{ha}{ }^{-1} \mathrm{~N}$ application treatment $(30.23 \%)$ and was equivalent to the 100 and $200 \mathrm{~kg} \mathrm{ha}^{-1} \mathrm{~N}$ doses with average values of 31.03 and $30.60 \%$, respectively (Table 1 ).

Jochims et al. (2010) conducted a study in millet pastures and found average NDF values of $59.29 \%$ when $\mathrm{N}$ was applied at $135 \mathrm{~kg} \mathrm{ha}^{-1}$ across three applications. In addition, Scaravelli et al. (2007) reported average NDF values of $57.39 \%$ in millet pastures at 53 days of vegetative growth and $80 \mathrm{~kg} \mathrm{ha}^{-1}$ of $\mathrm{N}$. These values are similar to those found in this study. Montagner et al. (2008) found an NDF value of $63.7 \%$ in a millet pasture, which was higher than the NDF values found in this study. Similarly, Costa et al. (2011) found a NDF content of $61.9 \%$ in a millet pasture 35 days after sowing. Camargo et al. (2009) reported an average NDF content of $50 \%$ for millet pastures with grazing 21 days after emergence and an $\mathrm{N}$ application of $100 \mathrm{~kg} \mathrm{ha}^{-1}$.

The NDF contents correspond to the recommendations by Van Soest (1994), who states that NDF is correlated with the animal's voluntary forage intake and acts as a limiting factor for forage intake. This effect is greater when the NDF is above $60 \%$. However, the 
intake of fibre by ruminants is important for the production of volatile fatty acids during ruminal fermentation and is an important energy source for the animal.

The ADF values that were obtained in the present study are very close to those recommended by Mertens (1994), who established an optimal maximum value of $30 \%$ for increasing forage intake and digestibility.

The NDF $\left(y=59.72-0.0592 x+0.00025 x^{2}\right)$ and ADF $\left(y=31.74-0.0195 x+0.00007 x^{2}\right)$ contents exhibited a quadratic effect as a function of the $\mathrm{N}$ dose.

Vitor et al. (2009) observed that NDF decreased linearly as a function of the $\mathrm{N}$ dose in elephant grass throughout the year. In this case, NDF values of 73.87 and $71.59 \%$ were reported for $\mathrm{N}$ doses of 100 and $700 \mathrm{~kg} \mathrm{ha}^{-1}$, respectively.

The average IVDDM values of the assessed millet cultivars were between 72.01 and $73.47 \%$. These values were similar to those found in the literature for $\mathrm{C} 3$ forage plants.

The high digestibility indices that were found in this study resulted from the excellent bromatological composition of the dry matter in the assessed cultivars. As shown in Table 1, the digestibility indices were unrelated to the $\mathrm{N}$ dose and sowing season.

Low concentrated protein concentrations in tropical forage grasses resulted from $\mathrm{C} 4$ photosynthetic metabolism as a function of the foliar anatomy and the $\mathrm{CO}_{2}$ fixation mechanism. However, the $\mathrm{N}$ and crude protein absorption capacity of the plant, considering the high content found in the forage, regardless of the applied $\mathrm{N}$ dose, was high as long as the soil fertility was corrected. Thus, we hypothesise that this plant uses a distinct physiological mechanism.

The average NDF and ADF contents were between 57.90 and $60.11 \%$ and between 30.23 to $32.00 \%$, respectively. These two parameters are important for determining the potential voluntary intake and digestibility of the forage dry matter.
Furthermore, the voluntary intake and digestibility reflect the nutritional value of the forage when combined with such factors as the crude protein content.

Dry matter digestibility depends on the ADF content and reflects the lignin content in the cell wall. When lignin is bound to cellulose and hemicellulose to form the lignocellulose complex, lignin becomes the most limiting factor for the degradation of structural carbohydrates in the rumen.

According to Van Soest (1994), N fertilisation reduces the digestibility of forage plants. This reduced digestibility is related to increasing nitrogenous compounds, increasing cell wall compounds and decreasing soluble carbohydrates (a fraction that is $100 \%$ digestible). However, this behaviour was not observed in this study. Instead, the digestibility indices remained constant, regardless of the applied $\mathrm{N}$ dose. In contrast, previous studies indicate that digestibility is generally not altered by increasing $\mathrm{N}$ doses in forage grasses at the same age. However, this behaviour changes with aging and reduces the IVDDM (Monson and Burton, 1982).

\section{CONCLUSIONS}

The bromatological composition of the assessed cultivars, regardless of the $\mathrm{N}$ dose, met the ruminant requirements for a grazing regime. Nitrogen fertilisation did not influence the IVDDM of the assessed millet cultivars. The BRS-1501 cultivar had a greater IVDDM in the summer sowing. Thus, this cultivar was influenced by sowing season.

\section{ACKNOWLEDGEMENTS}

The authors thank the Brazilian Federal Agency for the Support and Evaluation of Graduate Education (Coordenação de Aperfeiçoamento de Pessoal de Nível Superior - Capes) for providing financial support for this research. In addition, the authors thank the Federal University of Goiás and the Federal Institute of Goiás for supporting the implementation and execution of this research. 


\section{REFERENCES}

AMARAL, P.N.C.; EVANGELISTA, A.R.; SALVADOR, F.M.; PINTO, J.C. Qualidade e valor nutritivo da silagem de três cultivares de milheto. Cienc. Agrotec, v.32, p.611-617, 2008.

BRUM, M.S.; QUADROS, F.L.F.; MARTINS, J.D. et al. Sistemas de alimentação para a recria de ovinos a pasto:avaliação do desempenho animal e características da forragem. Cienc. Rural, v.38, p.191198, 2008.

CAMARGO, D.G.; ROCHA, M.G.; KOZLOSKI, G.V. et al. Consumo de forragem por cordeiras suplementadas em pastagem de milheto. Cienc. Rural, v.39, p.509-514, 2009.

COSTA, V.G.; ROCHA, M.G.; POTTER, L. et al. Comportamento de pastejo e ingestão de forragem por novilhas de corte em pastagens de milheto e papua. Rev. Bras. Zootec., v.40, p.251-259, 2011.

EMBRAPA. Centro Nacional de Pesquisa de Solos (Rio de Janeiro, RJ). Sistema Brasileiro de Classificação de Solos. Rio de Janeiro: Embrapa Solos, 2006. 306p.

FAGUNDES, J.L.; FONSECA, D.M.; MORAIS, R.V.M. et al. Avaliação das características estruturais do capim-Braquiária em pastagens adubadas com nitrogênio nas quatro estações do ano. Rev. Bras. Zootec., v.35, p.30-37, 2006.

JOCHIMS, F.; PIRES, C.C.; GRIEBLER, L. et al. Comportamento ingestivo e consumo de forragem por cordeiras em pastagem de milheto recebendo ou não suplemento. Rev. Bras. Zootec., v.39, p.572-581, 2010.

KOLLET, J.L.; DIOGO, J.M.S.; LEITE, G.G. Rendimento forrageiro e composição bromatológica de variedades de milheto (Pennisetum glaucum $(\mathrm{L}$.)R . BR.). Rev. Bras. Zootec., v.35, p.1308-1315, 2006.

MERTENS, D.R. Regulation of forage intake. In: FAHEY JR.,G.C.; COLLINS, M.; MERTENS, D.R. et al. Forage quality, evaluation and utilization. Madison: American Society of Agronomy, 1994. p.450-493.

MONSON, W.G.; BUSTON, G.W. Harvest frequency and fertilizer effects on yield, quality and persistence of eight bermudagrasses. Agronomy J., v.74, p.371374, 1982.
MONTAGNER, D.B.; ROCHA, M.G.; SANTOS, D.T. et al. Manejo da pastagem de milheto para recria novilha de corte. Ciênc. Rural, v.38, p.2293-2299, 2008.

PIRES, F.B.; ASSIS, R.L.; SILVA, G.P.; BRAZ, A.J.B.P. et al. Desempenho agronômico de variedades de milheto em razão da fenologia em pré-safra. Bioscie. J., v.23, p.41-49, 2007.

R Development Core Team. R: A language and environment for statistical computing. $\mathrm{R}$ Foundation for Statistical Computing, Vienna, Austria. ISBN 3900051-07-0, URL http://www.R-project.org. 2010.

REICHARDT, K. A água: absorção e translocação. In: FERRI, M.G. (Coord.) Fisiologia vegetal. 2.ed. São Paulo: EPU, 1985. p.20-21.

SANTOS, D.T.; ROCHA, M.G.; QUADROS, F.L.F. et al. Suplementos energéticos para recria de novilhas de corte em pastagens anuais: desempenho animal. Rev. Bras. Zootec., v.34, p.209-219, 2005.

SCARAVELLI, L.F.B.; PEREIRA, L.E.T.P.; OLIVO, C.J.; AGNOLIN, C.A. Produção e qualidade de pastagens de Coastcross-1 e milheto utilizadas com vacas leiteiras. Cienc. Rural, v.37, p.841-846, 2007.

SILVA, D.J.; QUEIROZ, A.C. Análise de alimentos (Métodos químicos e bi-ológicos). Viçosa, MG: Universidade Federal de Viçosa, 2002. 340p.

SIMILI, F.F.; GOMIDE, C.A.M.; MOREIRA, A.L. et al. Resposta do híbrido de sorgo-sudão à adubação nitrogenada e potássica: características estruturais e produtivas. Cienc. Agrotec., v.34, p.87-94, 2010.

SIMILI, F.F.; REIS, R.A.; FURLAN, B.N. et al. Resposta do híbrido de sorgo-sudão à adubação nitrogenada e potássica: composição química e digestibilidade in vitro da matéria orgânica. Cienc. Agrotec., v.32, p.474-480, 2008.

TILLEY, J.M.A.; TERRY, R.A. A two-stage technique for the in vitro digestion of forage crops. $J$. Brithsh Grassland Soc., v.18, p.104-111, 1963.

VAN SOEST, P.J. Nutritional ecology of the ruminat. 2.ed. New York: Cornell University Press, 1994. 476p.

VITOR, C.M.T.; FONSECA, D.M.; CÓSER, A.C. et $a l$. Produção de matéria seca e valor nutritivo de pastagem de capim-elefante sob irrigação e adubação nitrogenada. Rev. Bras. Zootec., v.38, p.435-442, 2009. 